\title{
Lactobacillus reuteri cell-free extracts against antibiotic-resistant bacteria
}

\author{
0. V. Knysh $\mathbb{D}^{* A-E}, A$. V. Martynov $\mathbb{D}^{C, E, F}$
}

State institution “I. I. Mechnikov Institute of Microbiology and Immunology of National Academy of Medical Sciences of Ukraine”, Kharkiv

A - research concept and design; B - collection and/or assembly of data; C - data analysis and interpretation; D - writing the article;

$\mathrm{E}$ - critical revision of the article; $\mathrm{F}$ - final approval of the article

The aim of the research was to evaluate the antimicrobial potential of cell-free extracts obtained in various ways from the probiotic strain Lactobacillus reuteri DSM 17938 with respect to their ability to influence the proliferation of antibiotic-resistant bacteria.

Materials and methods. Cell-free extracts were obtained: 1) from L. reutericell suspension, subjected to disintegration by repeated freezing-thawing, $L ; 2$ ) from $L$. reuteri culture, cultivated in its own disintegrate (ML); 3 ) from $L$. reuteri culture, cultivated in its own disintegrate supplemented with glycerol $(73.7 \mathrm{mg} / \mathrm{ml})$ and glucose $(72.1 \mathrm{mg} / \mathrm{ml})(\mathrm{MLG}) ; 4)$ from $L$. reuteri culture, cultivated in its own disintegrate supplemented with ascorbic acid $(20 \mathrm{mg} / \mathrm{ml})$ (MLA). Multidrug-resistant (MDR) and extensively drug-resistant (XDR) clinical isolates: Escherichia coli, Klebsiella pneumoniae, Lelliottia amnigena and Corynebacterium xerosis were used as a test cultures. The investigation of the inhibitory activity of cell-free extracts was carried out by spectrophotometric method using a microplate analyzer "Lisa Scan EM" (“Erba Lachema s.r.o.", Czech Republic).

Results. Cell-free extract L exerted predominantly stimulatory effect on the proliferation of all studied test cultures. Cell-free extract ML had significant inhibitory effect on the proliferation of $E$. coli and C. xerosis (growth inhibition indices were $24.8 \%$ and $96.1 \%$, respectively) and did not have significant effect on the proliferation of $K$. pneumoniae and $L$. amnigena. Cell-free extracts MLG and MLA caused pronounced inhibition of the proliferative activity of all tested microorganisms. Growth inhibition indices were: $75.0 \%$ and $90.7 \%$ (E. coli), $77.9 \%$ and $88.9 \%$ (K. pneumoniae), $40.9 \%$ and $77.9 \%$ (L. amnigena), $99 \%$ and $100 \%$ (C. xerosis), respectively.

Conclusions. The cell-free extracts obtained by cultivation of $L$. reuteri DSM 17938 in its own disintegrate supplemented with glycerol and glucose or ascorbic acid have shown a pronounced antimicrobial activity against antibiotic-resistant bacteria in vitro. After confirming safety and efficacy in vivo, they can be used to increase the efficiency of the therapy of diseases caused by antibiotic-resistant microorganisms. The results of the study indicate the prospects of obtaining probiotic derivatives with high antimicrobial activity by applying a combinatorial (precursor directed) biosynthesis strategy.

\section{Безкиітинні екстракти Lactobacillus reuteri проти антибіотикорезистентних бактерій}

\section{О. В. Книш, А. В. Мартинов}

Мета роботи - оцінити протимікробний потенціал безклітинних екстрактів, що отримані різними способами з пробіотичного штаму Lactobacillus reuteri DSM 17938, за їхньою здатністю впливати на проліферацію бактерій, стійких до антибіотиків.

Матеріали та методи. Безклітинні екстракти отримували: 1) із суспензії клітин L. reuteri, підданих дезінтеграції шляхом багаторазового заморожування-відтавання (L); 2) із культури L. reuteri, яку культивували в дезінтеграті власних клітин (ML); $3)$ із культури L. reuteri, яку культивували в дезінтеграті власних клітин, доповненому гліцерином (73,7 мг/мл) і глюкозою (72,1 мг/мл) (MLG); 4) із культури L. reuteri, яку культивували в дезінтеграті власних клітин, доповненому аскорбіновою кислотою (20 мг/Mл) (MLA). Клінічні ізоляти з множинною лікарською стійкістю (MDR) і з широкою лікарською стійкістю (XDR): Escherichia coli, Klebsiella pneumoniae, Lelliottia amnigena та Corynebacterium xerosis були використані як тестові культури. Дослідження інгібіторної активності безклітинних екстрактів проводили спектрофоотометричним методом із використанням мікропланшетного аналізатора «Lisa Scan EM» («Erba Lachema s.r.o.», Чеська Республіка).

Результати. Безклітинний екстракт L виявив переважно стимуляторну дію на проліферативну активність усіх досліджених культур. Безклітинний екстракт ML спричиняв суттєве пригнічення проліферації $E$. coli та C. xerosis (індекси пригнічення росту становили 24,8 \% та 96,1 \% відповідно) та не мав істотного впливу на проліферацію K. pneumoniae та L. amnigena. Безклітинні екстракти MLG і MLA викликали виражене пригнічення проліферативної активності всіх досліджених мікроорганізмів. Індекси пригнічення росту становили 75,0 \% та 90,7 \% (E. coli), 77,9 \% та 88,9 \% (K. pneumoniae), 40,9 \% та 77,9\% (L. amnigena), 99 \% та $100 \%$ (C. хеrosis) відповідно.

Висновки. Безклітинні екстракти, що отримані шляхом культивування L. reuteri DSM 17938 у дезінтеграті власних клітин, доповненому гліцерином із глюкозою або аскорбіновою кислотою, продемонстрували виражену протимікробну активність щодо антибіотикорезистентних бактерій in vitro. Після підтвердження безпечності та протимікробної активності in vivo вони можуть бути використані для підвищення ефективності терапії захворювань, котрі спричинені стійкими до антибіотиків мікроорганізмами. Результати дослідження свідчать про перспективність отримання пробіотичних похідних із високою протимікробною активністю шляхом застосування стратегії комбінаторного (спрямованого прекурсором) біосинтезу.
Key words: Lactobacillus reuteri derivatives, inhibitory activity, combinatorial (precursor-directed) biosynthesis.

Zaporozhye medical journal $2020 ; 22(4), 547-553$ *E-mail: knysh oksana@ukr.net

Ключові слова:

похіАні Lactobacillus reuteri, інгібіторна активність; комбінаторний (спрямований прекурсором) біосинтез.

Запорізький медичний журнал 2020. T. 22, № 4(121). C. 547-553 
Ключевые слова: производные Lactobacillus reuteri, ингибиторная активность, комбинаторный (направленный прекурсором) биосинтез.

Запорожский медицинский журнал 2020. T. 22, № 4(121). C. 547-553

\section{Бесклеточные экстракты Lactobacillus reuteri против антибиотикорезистентных бактерий}

\section{О. В. Кныш, А. В. Мартынов}

Цель работы - оценить противомикробный потенциал бесклеточных экстрактов, полученных разными способами из пробиотического штамма Lactobacillus reuteri DSM 17938, по их влиянию на пролиферацию бактерий, устойчивых к антибиотикам.

Материалы и методы. Бесклеточные экстракты получали: 1) из суспензии клеток L. reuteri, подвергнутых дезинтеграции путем многократного замораживания-оттаивания (L); 2) из культуры L. reuteri, культивированной в дезинтеграте собственных клеток (ML); 3) из культуры L. reuteri, культивированной в дезинтеграте собственных клеток, дополненном глицерином (73,7 мг/мл) и глюкозой (72,1 мг/мл) (MLG); 4) из культуры L. reuteri, культивированной в дезинтеграте собственных клеток, дополненном аскорбиновой кислотой (20 мг/мл) (MLA). Клинические изоляты с множественной лекарственной устойчивостью (MDR) и с широкой лекарственной устойчивостью (XDR): Escherichia coli, Klebsiella pneumoniae, Lelliottia amnigena и Corynebacterium xerosis были использованы как тестовые культуры. Исследование ингибиторной активности бесклеточных экстрактов проводили спектрофотометрическим методом с использованием микропланшетного анализатора «Lisa Scan EM» («Erba Lachema s.r.o.», Чешская Республика).

Результаты. Бесклеточный экстракт $L$ проявил преимущественно стимуляторное действие на пролиферативную активность всех исследованных культур. Бесклеточный экстракт ML вызывал значительное подавление пролиферации E. coli и C. xerosis (индексы угнетения роста составляли $24,8 \%$ и 96,1 \% соответственно) и не оказывал существенного влияния на пролиферацию K. pneumoniae и L. amnigena. Бесклеточные экстракты MLG и MLA вызывали выраженное угнетение пролиферативной активности всех исследованных микроорганизмов. Индексы угнетения роста составляли 75,0 \% и 90,7 \% (E. coli), 77,9 \% и 88,9 \% (K. pneumoniae), 40,9\% и 77,9\% (L. amnigena), 99 \% и 100 \% (C. хегоsis) соответственно.

Выводы. Бесклеточные экстракты, полученные путем культивирования L. reuteri DSM 17938 в собственном дезинтеграте, дополненном глицерином и глюкозой или аскорбиновой кислотой, продемонстрировали выраженную противомикробную активность в отношении антибиотикорезистентных бактерий in vitro. После подтверждения безопасности и противомикробной активности in vivo их можно использовать для повышения эффрективности терапии заболеваний, вызванных устойчивыми к антибиотикам микроорганизмами. Результаты исследования указывают на перспективность получения производных пробиотиков с высокой антимикробной активностью путем применения стратегии комбинаторного (направленного прекурсором) биосинтеза.

Uncontrolled, inappropriate and massive imprudent use of antibiotics has led to spread of antibiotic resistance among microorganisms. In recent years, antibiotic resistance has become a serious problem for modern medicine. Its spread entails the increasing morbidity and mortality due to infectious diseases [1,2]. In February 2017, the World Health Organization (WHO) published so-called "Global priority list of antibiotic-resistant bacteria to guide research, discovery, and development of new antibiotics" [3]. It lists the most important at the global level antibiotic-resistant bacteria, which constitute the greatest threat to human health. The priority pathogens list (PPL) is divided into three categories according to the level of priority for the development of new treatments. The Priority 1 category (critical) includes gram-negative bacteria: Acinetobacter baumanii, Pseudomonas aeruginosa and Enterobacteriaceae (Klebsiella pneumoniae, Escherichia coli, Enterobacter spp., Serratia spp., Proteus spp., Providencia spp., Morganella spp.). These bacteria are resistant to the wide range of antibiotics, including the most effective of existing antibiotics for the treatment of bacterial infections with multiple drug resistance: carbapenems and third-generation of cephalosporins. The second and third categories are high and medium priority pathogens (vancomycin-resistant Enterococcus faecium; methicillin-resistant, vancomycin intermediate and resistant Staphylococcus aureus and others). They can cause severe and often fatal infections. It is assumed that the PPL will be constantly updated in accordance with the new data.

The highest levels of antibiotic resistance are found among less pathogenic but more common bacteria that are prevalent in healthcare institutions [4]. Any opportunistic microorganism that becomes resistant to antibiotics, poses a threat to human health. During the last decade, some reports have described various cases of infections caused by opportunistic species of the genus Corynebacterium $[5,6]$. Corynebacterium xerosis, a representative of the normal flora of the human body, can cause serious and life-threatening diseases, such as septicaemia, endocarditis, pleuropneumonia, peritonitis, osteomyelitis, septic arthritis, mediastinitis, meningitis, ventriculitis, wound infections in immunocompromised or post-operative patients [7]. Some researchers report that among $C$. xerosis strains isolated from patients with urogenital pathology and healthy people, the number of antibiotic resistant pathogens reached $96.0 \%$. More than $58 \%$ of these strains showed resistance to three or more antibiotics [8]. The hazard to patient health and life dramatically increases when a pathogen exhibits resistance to antibiotics, which are usually effective. The emergence of drug resistance among coryneform isolates is of most concern and requires constant monitoring for the correct and timely treatment of patients with such infections [5].

The basis for solving the problem of antibiotic resistance is the WHO global plan of action to combat the resistance of microorganisms to antimicrobial drugs, which involves strengthening the groundbreaking work, research and development of new antimicrobials. It is hoped that there is an enormous potential of alternative unconventional approaches to antimicrobial therapy: the use of antibodies, probiotics, bacteriophages and lysins, vaccines, antimicrobial peptides (AMPs), host/ innate defense peptides (HDPs/IDRs), antibiofilm peptides, immune stimulation and others [9]. There are two promising microbial strategies for restricting antibiotic resistance spread: bacteriophage- and bacteria-based. Commensal 
("health-promoting", "beneficial" or probiotic) bacteria can inhibit growth and transmission of antibiotic-resistant pathogens by direct and indirect ways: by their own production of antimicrobial substances (bacteriocins, antimicrobial peptides and organic acids) and by causing the activation of host defense mechanisms (the production of antimicrobial peptides and IgA, an increase in the mucus layer thickness). They not only contribute to elimination of antibiotic-resistant pathogens but there is also evidence that they may be able to inhibit the horizontal transfer of antibiotic resistance genes [10].

It is known that the beneficial effect of probiotic bacteria on the host organism is realized due to the action of their structural components and metabolites [11]. Therefore, using the biological activity of the probiotic derivatives can also be considered as an alternative way to combat the spread of antibiotic-resistant bacteria $[10,11]$. Recent studies have confirmed the validity of this approach to the fight against antibiotic-resistant strains. Although the results were encouraging, they showed the variability and selectivity of the antimicrobial activity of the probiotic cell-free supernatants against various antibiotic-resistant microorganisms $[12,13]$.

L. reuteri is one of the heterofermentative lactobacilli with a powerful probiotic potential $[14,15]$. However, the functional properties of different strains of $L$. reuteri are not the same. For example, the different strains of L. reuteri are capable of producing specific antimicrobial substances (reutericin, reutericycin and reuterin), but there is no evidence that single strain is capable of producing two or more of them simultaneously [16]. The spectrum of the produced antimicrobial metabolites varies a lot according to the culture conditions of the producer [17]. In vitro and in vivo studies (in animal models and in clinical trials), which proved the anti-inflammatory, antimicrobial and immunotropic activity of lactobacillus species $L$. reuteri, were carried out using various strains. L. reuteri ATCC 55730 and ATCC 17938 are the most commonly used strains in human trials. Research interest in this probiotic is due not only to its well-known immunotropic, anti-inflammatory and antimicrobial activity. Recent attention of researchers has been focused on the $L$. reuteri as a producer of reuterin, which is a precursor-induced antimicrobial agent $[18,19]$.

Precursor-directed biosynthesis strategy is a promising way to develop new antimicrobials, in particular against antibiotic-resistant pathogens. Obviously, this approach involves the study of various substances as precursors. In our opinion, one of the relevant candidates for the role of a precursor is ascorbic acid. There is convincing data on the pronounced intrinsic antimicrobial activity of ascorbic acid $[20,21]$. However, our preliminary studies have shown its weak antimicrobial activity against antibiotic-resistant strains at concentrations of $0.15-0.60 \%$.

\section{Aim}

The aim of this research was to evaluate the antimicrobial potential of cell-free extracts obtained in various ways from the probiotic strain Lactobacillus reuteri DSM 17938 with respect to their ability to influence the proliferation of antibiotic-resistant bacteria.

\section{Materials and methods}

Probiotic strain L. reuteri DSM 17938 (from dietary supplement "BioGaia ORS", BioGaia AB, Sweden) was used as source of biologically active structural components and as producer of metabolites. The additional components included in the dietary supplement were removed as follows: the lyophilisate from the sachet was rehydrated with distilled water and centrifuged; the supernatant with the dissolved salts was decanted. Precipitated bacterial cells were inoculated into a liquid nutrient medium: thioglycollate medium or Man, Rogosa and Sharpe broth (Biolife, Italy) and cultivated for 20-24 hours. After checking the purity, the culture was washed three times with sterile saline solution to remove the culture medium. Bacterial suspensions with an optical density of 10 units on the MacFarland scale were prepared from the precipitated cells. Cell-free extracts were obtained from disintegrates (disintegrated cell suspensions) and cultures of lactobacilli.

Disintegrates were prepared by a repeated freezingthawing of the bacterial suspensions in physiological saline with optical density of 10.0 units according to the McFarland scale (measured with Densi-La-Meter, Lachema, Czech Republic). 10 cycles of freeze-thawing were carried out according to the following regimen: passive cooling and freezing in the freezing chamber of Samsung RB29FSRNDSA refrigerator down to $-23^{\circ} \mathrm{C}$, thawing in water bath at $37^{\circ} \mathrm{C}$ up to complete thawing.

Probiotic cultures were obtained by cultivating of lactobacilli in their own disintegrates without supplementation and supplemented with glycerol \& glucose or ascorbic acid. To this end, the probiotic suspension in physiological saline of turbidity 10.0 units on the McFarland scale was added into disintegrate with or without supplementation in $1: 9$ ratio and cultured at $37^{\circ} \mathrm{C}$ for 72 hours in the microaerobic conditions.

Disintegrates and cultures of lactobacilli were centrifuged at $3000 \mathrm{~g}$ for 10 minutes in order to remove remained cells and cellular debris. Supernatant was passed through sterile membrane filters with pore diameter of 0.2 micron (Vladipor, RF).

Four cell-free extracts have been studied:

1) $L-$ filtrate of $L$. reuteri disintegrate;

2) $M L-$ filtrate of $L$. reuteri culture, cultivated in its own disintegrate;

3) MLG - filtrate of L. reuteri culture, cultivated in its own disintegrate supplemented with glycerol $(73.7 \mathrm{mg} / \mathrm{ml})$ and glucose $(72.1 \mathrm{mg} / \mathrm{ml})$;

4) MLA-filtrate of $L$. reuteri culture, cultivated in its own disintegrate supplemented with ascorbic acid $(20 \mathrm{mg} / \mathrm{ml})$.

Clinical isolates: E. coli, K. pneumoniae, L. amnigena and $C$. xerosis were used as a test cultures. They were isolated from patients with urinary tract infection or purulentinflammatory surgical diseases. The cultures were stored in the Collection of Microorganisms of the Laboratory of Respiratory Infections Prevention of IMI NAMS, Kharkiv, Ukraine. All isolates were identified based on the phenotypic traits: morphological, tinctorial, cultural, physiological and biochemical properties. Susceptibility of bacteria toward antimicrobial agents of different classes was determined on Mueller Hinton agar (Merck, Germany) by the KirbyBauer disc diffusion test. Antibiotic-containing disks were produced by JSC Aspect (Ukraine) and company HiMedia (India). The lists of tested antimicrobial agents corresponded 
to those previously published [22]. Clinical isolates were considered as resistant, intermediate or susceptible according to inhibition zone diameters. Quality control was performed using E. coli ATCC 25922 and Pseudomonas aeruginosa ATCC 27853. Susceptibility interpretations were conducted considering CLSI (Clinical and Laboratory Standards Institute) document M100-S26 (Performance Standards for Antimicrobial Susceptibility Testing, 2016) and/or EUCAST breakpoints (European Committee on Antimicrobial Susceptibility Testing, 2019. Breakpoint tables for interpretation of MICs and zone diameters. Version 9.0). Based on the antimicrobial resistance profiles, all isolates were categorized according to the criteria previously proposed [22].

Preparation of the inoculum: the test cultures were cultivated overnight aerobically at $37{ }^{\circ} \mathrm{C}$ on MuellerHinton agar (Merck, Germany). After verifying the purity of the culture, some colonies from the overnight incubated agar medium were emulsified in a physiological saline for obtaining a suspension of turbidity 0.5 on the McFarland scale. The turbidity of the suspension was measured using the Densi-La-Meter II device (PLIVA-Lachema Diagnostika, Czech Republic).

Effect of cell-free extracts on proliferative activity of clinical isolates was studied using spectrophotometric microplate method previously described in detail [23]. Briefly, an increase in the optical density of test cultures was compared in the presence (test samples) or absence (control samples) of the studied cell-free extracts. Test cultures were exposed to whole cell-free extracts for one hour and after adding of Meat-Peptone Broth (HiMedia, India), the concentration of the extracts in the incubation medium was $30 \%$ vol. The concentration of test cultures in the incubation medium was $\sim 10^{5} \mathrm{CFU} / \mathrm{ml}$. The optical density (OD) of the wells was measured at $578 \mathrm{~nm}$ using a microtiter-plate reader "Lisa Scan EM" ("Erba Lachema s.r.o.", Czech Republic) immediately before and after incubation of plates aerobically for 24 hours at $35-37^{\circ} \mathrm{C}$ in static conditions. Growth inhibition (or stimulation) indices were calculated by the formula: $\mathrm{GI}(\mathrm{GSI})=\left(\Delta \mathrm{OD}-\Delta \mathrm{OD}_{\mathrm{PC}}\right) \div$ $\Delta \mathrm{OD}_{\mathrm{PC}} \times 100 \%$, where $\Delta \mathrm{OD}$ and $\Delta \mathrm{OD}_{\mathrm{PC}}$ were the changes in optical density of the control and test samples within 24 hours, PC - positive control sample containing test-culture without cell-free extract.

All experiments were performed three times. Each sample was tested in triplicate. Average values of obtained indices $(\triangle O D)$ with standard deviations (SD) were determined. Obtained data were statistically processed with Excel 2010 software (Microsoft, USA). One-way analysis of variance (ANOVA) followed by post hoc Bonferroni's multiple comparison test was performed. Differences were considered significant at $\mathrm{P}<0.05$.

The study was conducted in the Laboratory of Respiratory Infections Prevention of IMI NAMS.

\section{Results}

In accordance with the results of the antibiotic susceptibility study by disc diffusion, test clinical isolates were defined as MDR (multidrug-resistant) and XDR (extensively drugresistant). It is important to note that $E$. coli, K. pneumonia and $L$. amnigena were resistant to carbapenems and third-generation of cephalosporins. This allowed them to be subsumed under the first category according to the level of priority for the development of new treatments [3]. C. xerosis was resistant to penicillins, fluoroquinolones, aminoglycosides, macrolides, tetracyclines, moderately resistant to rifampicin and susceptible only to vancomycin and linezolid.

Incubation of two test-cultures, L. amnigena and C. xerosis, in the cultivation medium containing cell-free extract $L$ was accompanied by pronounced increase in their optical density (Fig.1). The GSIs calculated by the formula for these cultures were $56.0 \%$ and $71.7 \%$, respectively. E. coli and K. pneumoniae were cultures, the optical density increase of which in the presence of this extract was not significantly higher than in case of its absence (GSIs were 17.3 and $4.3 \%$, respectively). Thus, extract $L$ did not significantly affect the proliferative activity of some cultures and significantly stimulated the growth of others. Notably, the differences in the extract $L$ effect on cultures did not depend on their Gram stain.

As shown in Fig. 2, the presence of ML extract in the cultivation medium did not significantly affect the optical density increase of two test-cultures: $K$. pneumoniae and L. amnigena. GSIs, calculated for them, were $1.8 \%$ and $18.3 \%$, respectively. The optical density increase of other two cultures (E. coli and C. xerosis) in the presence of this extract was significantly inhibited: Glls were $24.8 \%$ and $96.1 \%$, respectively. There was no association between the nature of the ML extract effect and Gram stain of the tested cultures.

MLG cell-free extract showed remarkable antibacterial activity against all studied antibiotic resistant test-cultures regardless of their Gram stain (Fig. 3). This extract presented excellent inhibitory activity against $C$. xerosis. The optical density increase of this test-culture in the presence of MLG extract in the cultivation medium was negligible or absent (GIl was 99 \%). This extract also possesses moderate antibacterial activities against $E$. coli, K. pneumoniae and $L$. amnigena as evidenced by a significant inhibition of the optical density increase of these test cultures in the presence of MLG extract in the incubation medium compared to controls (Glls were $75 \%, 77.9 \%$ and $40.9 \%$, respectively).

As can be seen from the data presented in Fig. 4, MLA extract showed high inhibitory activity against all studied test-cultures. Growth of $C$. xerosis was ceased under the influence of this extract. The optical density increase of the other three test cultures (E. coli, K. pneumoniae and L. amnigena) in the presence of this extract was small. Glls, calculated for them, were $90.7 \%, 88.9 \%$ and $77.9 \%$, respectively.

\section{Discussion}

The cell-free extract $L$ contains the disintegration $L$. reuteri products obtained by repeated cyclic freeze-thawing. At the freeze-thawing stages, cells receive sublethal and lethal damage through undergoing the thermal, osmotic, thermomechanical, dehydration, rehydration shock and mechanical disruption by ice crystals. Because of cellular integrity violation, not only superficial, but also intracellular structural components and metabolites of 


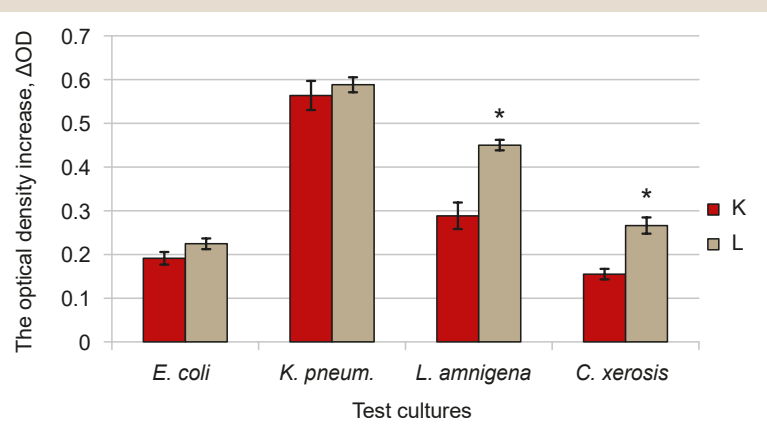

Fig. 1. The effect of cell-free extract $L$ on the proliferation of antibiotic-resistant testcultures (average $\Delta O D \pm S D$ at $578 \mathrm{~nm}, n=3$ ): K: positive control; $L$ : filtrate of $L$. reuter disintegrate; *: the differences are significant compared to the $K ; P<0.05$.

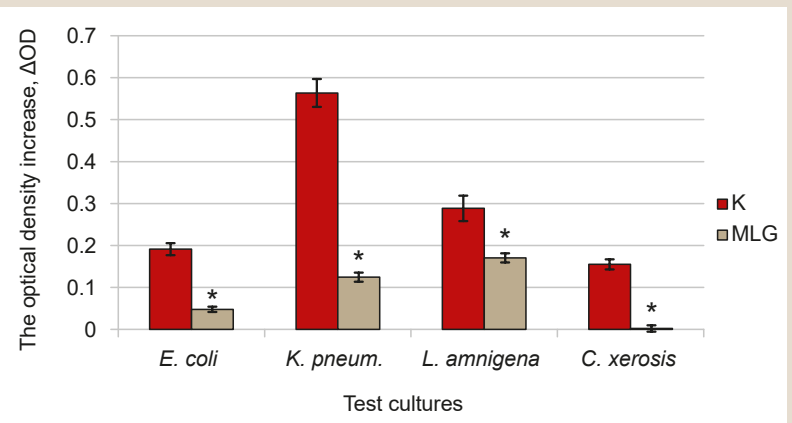

Fig. 3. The effect of cell-free extract MLG on the proliferation of antibiotic-resistant test-cultures (average $\triangle \mathrm{OD} \pm \mathrm{SD}$ at $578 \mathrm{~nm}, \mathrm{n}=3$ ): K: positive control; MLG: filtrate of $L$. reuteri culture, cultivated in its own disintegrate supplemented with glycerol and glucose; *: the differences are significant compared to the $\mathrm{K} ; \mathrm{P}<0.05$.

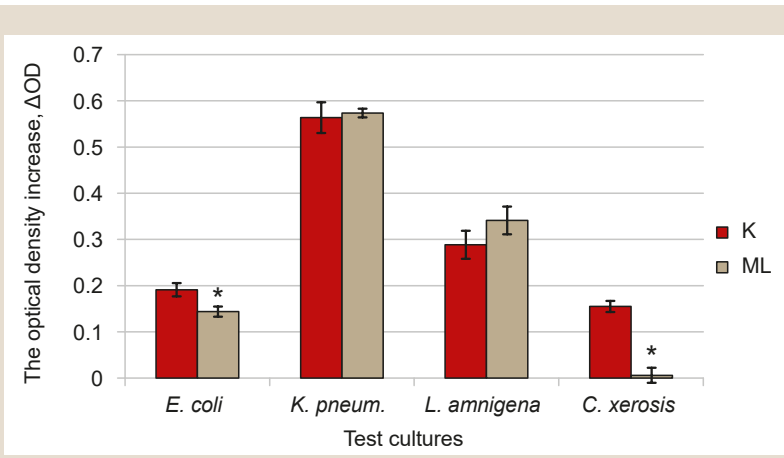

Fig. 2. The effect of cell-free extract ML on the proliferation of antibiotic-resistant testcultures (average $\triangle O D \pm S D$ at $578 \mathrm{~nm}, n=3$ ): K: positive control; $M L$ : filtrate of $L$. reuteri culture, cultivated in its own disintegrate; *: the differences are significant compared to the $\mathrm{K} ; \mathrm{P}<0.05$.

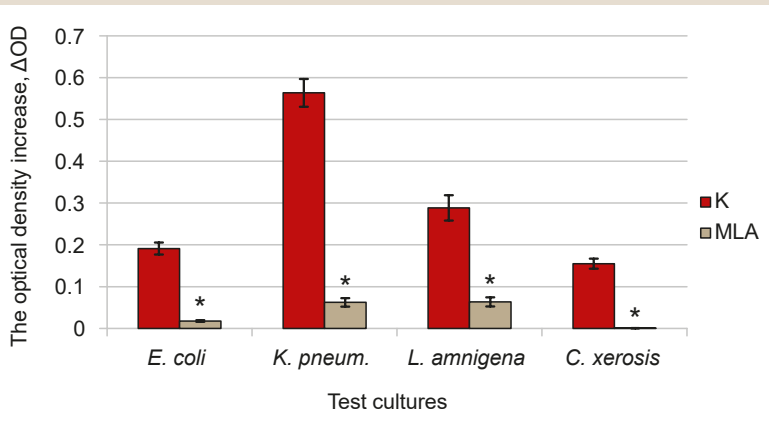

Fig. 4. The effect of cell-free extract MLA on the proliferation of antibiotic-resistant test-cultures (average $\triangle \mathrm{OD} \pm \mathrm{SD}$ at $578 \mathrm{~nm}, \mathrm{n}=3$ ): K: positive control; MLA: filtrate of L. reuteri culture, cultivated in its own disintegrate supplemented with ascorbic acid; *: the differences are significant compared to the $\mathrm{K} ; \mathrm{P}<0.05$ stressed cells enter the extracellular space. Obviously, the extract from $L$. reuteri disintegrate contains both MAMPs (microbe-associated molecular patterns) and DAMPs (damage-associated molecular patterns). It is known that these bacterial structures possess powerful bioregulatory potential. For example, cold shock proteins have the ability to orchestrate multiple cellular processes, including proliferation and differentiation by regulation of transcription, translation, and splicing [24]. The results of this research stage indicate that the cell-free extract obtained from $L$. reuteri disintegrate contains derivatives of lactobacilli that cause a predominantly stimulating effect on proliferation of antibiotic resistant test-cultures. Since the extract has a complex composition, only the fractionation and studying the effects of its individual fractions will help to elucidate the mechanism of its action.

In contrast to the $L$ extract, which contains the disintegration products of bacteria, the cell-free extract ML contains lactobacillus metabolites obtained by cultivation them in their own disintegrates. It is known that $L$. reuteri are capable of producing a number of metabolites with antimicrobial activity: organic acids (lactic, phenyllactic and acetic), ethanol, hydrogen peroxide, bacteriocin-like high-molecular-mass compounds and others [14,15,17]. Production of antimicrobial compounds strictly depends not only on the lactobacillus strain, but also on the cultivation conditions $(\mathrm{pH}$, temperature and the adequate concentration of specific precursors, glucose, salts, and enzyme cofactors) [17]. Clearly, the ability of ML extracts to inhibit the proliferation of $E$. coli and $C$. xerosis is associated with the presence of the above-mentioned antimicrobial substances. At the same time, the antimicrobial potential of this extract is insufficient to suppress the proliferative activity of antibiotic resistant isolates of $K$. pneumoniae and $L$. amnigena. To date, a number of studies have been published, indicating the antimicrobial activity of L. reuteri metabolites obtained by cultivation of producer on conventional nutrient media [13,25-27]. The results of these studies allow us to draw some conclusions: the main extracellular antibacterial agents of lactobacilli are organic acids ( $\mathrm{pH}$-neutralization elicited the most significant impact on the antimicrobial activity of cell-free supernatants, while proteinase and heat treatment had little or no impact); longer cultivation of the producer in microaerobic conditions results in stronger inhibition of test bacteria. Unfortunately, among the published works there are few studies on the effect of $L$. reuteri metabolites on antibiotic resistant bacteria. Some authors have shown that supernatant of $L$. reuteri strain isolated from a commercial oral product exhibits relatively weak inhibitory activity (20\%) against MDR clinical isolates of $P$. aeruginosa [27]. Despite the differences in the method of obtaining the metabolite-containing product and the method of studying its antimicrobial activity, the results obtained by Jamalifar et al. and the results of this study on the effect of the ML extract on Gram-negative bacteria are similar. In contrast to the data obtained in this study, other authors found out a significant antagonistic activity of L. reuteriagainst multiple antibiotic-resistant $K$. pneumoniae 
strains [13]. The suppression degree of the K. pneumoniae by $L$. reuterivaried in the range of $56-73 \%$. However, such pronounced inhibition was obtained by the co-cultivation of microorganisms and may indicate the existence of a mechanism for the induction of $L$. reuteriantimicrobial activity by co-cultured microorganism. Cell-free supernatants of other Lactobacillus species (L. acidophilus, L. paracasei, L. delbrueckii, L. casei, L. helveticus, L. brevis, L. salivarius, L. fermentum, $L$. rhamnosus, $L$. animalis, and $L$. plantarum) showed different antimicrobial activity against a number of MDR uropathogens: Candida albicans, K. pneumoniae, P.aeruginosa, E. coli, and Enterococcus fecalis. Only one indicator strain (Staphylococcus aureus DPC 6867) showed resistance to all the lactobacillus supernatants [12]. Among fifty-seven Lactobacillus spp. strains, only five exerted high anti-carbapenem-resistant Enterobacteriaceae activity. The minimum inhibitory percentage of supernatants of these five strains ranged from $10 \%$ to $30 \%$ [28]. These data indicate the variability and selectivity of the antimicrobial activity of cell-free supernatants of probiotic origin.

It is known that $L$. reuteri can produce and excrete reuterin $[14,15]$. This antimicrobial compound is able to inhibit or inactivate a wide range of microorganisms: bacteria, fungi, protozoa and viruses. At the same time, $L$. reuteri strains are resistant to it. Reuterin is a mixture of different forms of 3-hydroxypropionaldehyde (3-HPA). Production of reuterin is the result of glycerol fermentation. In the gastrointestinal tract, where $L$. reuteri usually inhabited, small amounts of glycerol are available. However, for complete growth inhibition, for example, enterobacteria $L$. reuteri requires at least $0.2 \%$ of glycerol. These circumstances should encourage researchers to reconsider existing methods of using probiotic supplements for more effective clinical use of their antimicrobial potential [18]. Precursor-directed antimicrobial biosynthesis is considered as a promising strategy for next-generation probiotics development [19]. The results of this study have confirmed its promise. The cell-free extracts, obtained by cultivating $L$. reuteri in its own disintegrate supplemented with glycerol \& glucose, have shown high and moderate antimicrobial activity against antibiotic-resistant bacterial strains. However, it is worth remembering that in vitro activity cannot be equated with an in vivo effect. In addition, there are circumstances that must be taken into account before in vivo use of the extracts thus obtained; it is known that reuterin can be reversibly converted into the toxic substance acrolein. Moreover, some authors have suggested that acrolein is an active compound responsible for the antimicrobial activity attributed to reuterin [29]. Therefore, thorough toxicological studies are necessary before the therapeutic use of these extracts.

MLA cell-free extract exerted the most pronounced antimicrobial activity against antibiotic-resistant bacteria among all the studied extracts. The results are consistent with the data from other authors who previously reported inhibitory activity of ascorbic acid against Gram-positive and Gram-negative bacteria [20,21,30]. Some authors have suggested that the antibacterial activity of ascorbic acid was not due to acidification or a decrease in $\mathrm{pH}$, but owing to specific action of ascorbic acid on the cell membrane or cell enzymes [21]. Other authors experimentally confirmed the existence of another mechanism of bacterial growth inhibition (another than acidification) [30]. The discovered in this study high inhibitory effect of MLA extract cannot be explained only by the intrinsic antimicrobial activity of ascorbic acid. Firstly, ascorbic acid at a similar concentration had a significantly weaker inhibitory effect on the studied microorganisms. Secondly, a chromatographic study showed that the substance found in the greatest quantity in MLA cell-free extract was a modified ascorbic acid (data not shown). It is possible that just the modified ascorbic acid is responsible for the high antimicrobial activity of MLA extract. Thirdly, the high antimicrobial potential of the MLA extract can be partially explained by the presence of others organic acids, in particular lactic acid. The synergistic inhibitory effect caused by combination of ascorbic and lactic acid was discovered earlier [30]. Further study is necessary to clarify the mechanism of antimicrobial activity of MLA extract.

\section{Conclusions}

1. The cell-free extracts obtained by cultivation of L. reuteri DSM 17938 in its own disintegrate supplemented with glycerol and glucose or ascorbic acid have shown a pronounced antimicrobial activity against antibiotic-resistant bacteria in vitro.

2. After confirming safety and efficacy in vivo, they can be used to increase the efficiency of the therapy of diseases caused by antibiotic-resistant microorganisms.

3. The results of the study indicate the prospects of obtaining probiotic derivatives with high antimicrobial activity by applying a combinatorial (precursor directed) biosynthesis strategy.

Prospects for further research: obtained results will be used to develop new antimicrobial agents of probiotic origin, effective against antibiotic-resistant bacteria.

\section{Funding}

The study is a fragment of the research project of the Laboratory of Respiratory Infections Prevention, State Institution "I. I. Mechnikov Institute of Microbiology and Immunology of the National Academy of Medical Sciences of Ukraine", "Microbiological characteristic of new structural and metabolic complexes of lacto- and bifidoprobiotics", state registration No. $0119 U 100686$ (2019-2021).

Conflicts of interest: authors have no conflict of interest to declare. Конфлікт інтересів: віАсутній.

Надійшла Ао реАакції / Received: 16.12.2019

Після Аоопрацювання / Revised: 26.02.2020

Прийнято Ао Аруку / Accepted: 10.03.2020

Information about authors:

Knysh 0. V., MD, PhD, Senior Researcher, Laboratory of

Respiratory Infections Prevention, State Institution "I. I. Mechnikov Institute of Microbiology and Immunology of the National Academy of Medical Sciences of Ukraine", Kharkiv.

ORCID ID: 0000-0002-4105-1299

Martynov A. V., PhD, Dr. hab., Professor, Head of the Laboratory and Clinical Department of Molecular Immunopharmacology, State Institution "I. I. Mechnikov Institute of Microbiology and Immunology of the National Academy of Medical Sciences of Ukraine", Kharkiv.

ORCID ID: 0000-0003-1428-0085 
Відомості про авторів:

Книш О. В., канА. меА. наук, старший науковий співробітник лабораторії профікактики краплинних інфекцій, АУ "Інститут мікробіології та імунології імені І. І. Мечникова НАМН України", м. Харків.

Мартинов А. В., А-р фарм. наук, професор, зав. лабораторії та клінічного відділу молекулярної імунофармакології, АУ "Інститу мікробіології та імунології імені І. І. Мечникова НАМН України", м. Харків.

\section{Сведения об авторах:}

Кныш О. В., канА. меА. наук, старший научный сотрудник лаборатории профилактики капельных инфекций, ГУ “Институт микробиологии и иммунологии имени И. И. Мечникова НАМН Украины", г. Харьков.

Мартынов А. В., А-р фарм. наук, профессор, зав. лабораторией и клиническим отАелом молекулярной иммунофармакологии, ГУ "Институт микробиологии и иммунологии имени И. И. Мечникова НАМН Украины", г. Харьков.

\section{References}

[1] de Kraker, M. E. A., Stewardson, A. J., \& Harbarth, S. (2016). Will 10 Million People Die a Year due to Antimicrobial Resistance by 2050? PLOS Medicine, 13(11), Article e1002184. https://doi.org/10.1371/ journal.pmed.1002184

[2] Li, B., \& Webster, T. J. (2018). Bacteria antibiotic resistance: New challenges and opportunities for implant-associated orthopedic infections. Journal of Orthopaedic Research, 36(1), 22-32. https://doi. org/10.1002/jor.23656

[3] World Health Organization. (2017, February 27). Global priority list of antibiotic-resistant bacteria to guide research, discovery, and development of new antibiotics. https://www.who.int/medicines/publications/ global-priority-list-antibiotic-resistant-bacteria/en/

[4] Keith, J. W., \& Pamer, E. G. (2018). Enlisting commensal microbes to resist antibiotic-resistant pathogens. Journal of Experimental Medicine, 216(1), 10-19. https://doi.org/10.1084/jem.20180399

[5] Rizvi, M., Rizvi, M. W., Shaheen, Sultan, A., Khan, F., Shukla, I., \& Malik, A. (2013). Emergence of coryneform bacteria as pathogens in nosocomial surgical site infections in a tertiary care hospital of North India. Journal of Infection and Public Health, 6(4), 283-288. https://doi. org/10.1016/j.jiph.2013.01.005

[6] Nayak, N., Parajuli, R., Hamal, D., Shrestha, R., Neupane, S., Bhatta, D. R., Hs, S., Gokhale, S., Sharma, B., \& Baral, N. (2017). Non-diphtheriae Corynebacterium species as emerging pathogens: case series from a tertiary care hospital in western Nepal. Malaysian Journal of Medical Research, 1(1), 19-24. https://ejournal.lucp.net/ index.php/mimr/article/view/105/84

[7] Sasikumari, O., \& Thomas, S. (2018). Isolation of Corynebacterium xerosis from clinical specimens: A case series. Journal of The Academy of Clinical Microbiologists, 20(1), 43-45. https://doi.org/10.4103/ jacm.jacm $68 \quad 16$

[8] Kharseeva, G. G., Voronina, N. A., Gasretova, T. D., Sylka, O. I., \& Tyukavkina, S. Yu. (2017). Antibiotikorezistentnye shtammy nedifteriinykh korinebakterii [Antibiotics resistance of Corynebacterium non diphtheriae strains]. Zhurnal mikrobiologii, epidemiologii i immunobiologii, (2), 3-8. https://doi.org/10.36233/0372-9311-2017-2-3-8 [in Russian].

[9] Czaplewski, L., Bax, R., Clokie, M., Dawson, M., Fairhead, H., Fischetti, V.A., Foster, S., Gilmore, B. F., Hancock, R. E. W., Harper, D., Henderson, I. R., Hilpert, K., Jones, B. V., Kadioglu, A., Knowles, D., Ólafsdóttir, S., Payne, D., Projan, S., Shaunak, S., ... Rex, J. H. (2016). Alternatives to antibiotics - a pipeline portfolio review. The Lancet Infectious Diseases, 16(2), 239-251. https://doi.org/10.1016/s1473-3099(15)00466-1

[10] Wong, W. F., \& Santiago, M. (2017). Microbial approaches for targeting antibiotic-resistant bacteria. Microbial Biotechnology, 10(5), 1047-1053. https://doi.org/10.1111/1751-7915.12783

[11] Singh, A., Vishwakarma, V., \& Singhal, B. (2018). Metabiotics: The Functional Metabolic Signatures of Probiotics: Current State-of-Art and Future Research Priorities - Metabiotics: Probiotics Effector Molecules. Advances in Bioscience and Biotechnology, 9(4), 147-189. https://doi. org/10.4236/abb.2018.94012

[12] Manzoor, A., UI-Haq, I., Baig, S., Qazi, J. I., \& Seratlic, S. (2016). Efficacy of Locally Isolated Lactic Acid Bacteria Against Antibiotic-Resistant Uropathogens. Jundishapur Journal of Microbiology, 9(1), Article e18952. https://doi.org/10.5812/jim.18952

[13] Fedorova, T. V., Vasina, D. V., Begunova, A. V., Rozhkova, I. V. Raskoshnaya, T. A., \& Gabrielyan, N. I. (2018). Antagonistic Activity of Lactic Acid Bacteria Lactobacillus spp. against Clinical Isolates of Klebsiella pneumoniae. Applied Biochemistry and Microbiology, 54(3), 277-287. https://doi.org/10.1134/s0003683818030043
[14] Britton, R. A. (2017). Chapter 8 - Lactobacillus reuteri. In M. H. Floch, Y. Ringel, \& W. Allan Walker (Eds.), The Microbiota in Gastrointestinal Pathophysiology (pp. 89-97). ScienceDirect; Academic Press. https://doi.org/10.1016/b978-0-12-804024-9.00008-2

[15] Mu, Q., Tavella, V. J., \& Luo, X. M. (2018). Role of Lactobacillus reuteri in Human Health and Diseases. Frontiers in Microbiology, 9, Article 757. https://doi.org/10.3389/fmicb.2018.00757

[16] Reginensi, S. M., Olivera, J. A., Bermúdez, J., \& González, M. J. (2016) Lactobacillus in the Dairy Industry: From Natural Diversity to Biopreservation Resources. In S. Castro-Sowinski (Ed.), Microbial Models: From Environmental to Industrial Sustainability (Vol. 1, pp. 57-81). Springer. https://doi.org/10.1007/978-981-10-2555-6 4

[17] Greifová, G., Májeková, H., Greif, G., Body, P., Greifová, M., \& Dubničková, M. (2017). Analysis of antimicrobial and immunomodulatory substances produced by heterofermentative Lactobacillus reuteri. Folia Microbiologica, 62(6), 515-524. https://doi.org/10.1007/s12223017-0524-9

[18] Etchebehere, M. C., Piveta, C., \& Levy, C. E. (2017). The influence of glycerol upon L. reuteri activity against enteropathogens. Medical Express, 4(6), Article M170606. https://doi.org/10.5935/medicalexpress.2017.06.06

[19] Spinler, J. K., Auchtung, J., Brown, A., Boonma, P., Oezguen, N. Ross, C. L., Luna, R. A., Runge, J., Versalovic, J., Peniche, A., Dann, S. M., Britton, R. A., Haag, A., \& Savidge, T. C. (2017). Next-Generation Probiotics Targeting Clostridium difficile through Precursor-Directed Antimicrobial Biosynthesis. Infection and Immunity, 85(10), Article e00303-17. https://doi.org/10.1128/iai.00303-17

[20] Mathew, S., Verghese, R., \& David, A. (2017). Antimicrobial activity of Vitamin $C$ demonstrated on uropathogenic Escherichia coli and Klebsiella pneumoniae. Journal of Current Research in Scientific Medicine, 3(2), 88-93. https://doi.org/10.4103/jcrsm.jcrsm 3517

[21] Panda, L., \& Arul, J. (2018, March 18-22). AGFD 187: Antibacterial Activity of Ascorbic acid: $p H$ effect, specific action or both? Body. 255th ACS National Meeting, AGFD Symposium, New Orleans, LA. https:/l doi.org/10.13140/RG.2.2.22321.48482

[22] Magiorakos, A. -P., Srinivasan, A., Carey, R. B., Carmeli, Y., Falagas, M. E., Giske, C. G., Harbarth, S., Hindler, J. F., Kahlmeter, G., Olsson-Liljequist, B., Paterson, D. L., Rice, L. B., Stelling, J., Struelens, M. J., Vatopoulos, A., Weber, J. T., \& Monnet, D. L. (2012). Multidrug-resistant, extensively drug-resistant and pandrug-resistant bacteria: an international expert proposal for interim standard definitions for acquired resistance. Clinical Microbiology and Infection, 18(3), 268281. https://doi.org/10.1111/j.1469-0691.2011.03570.x

[23] Knysh, O. V., Isayenko, O. Y., Voyda, Y. V., Kizimenko, O. O., \& Babych, Y. M. (2019). Influence of cell-free extracts of Bifidobacterium bifidum and Lactobacillus reuteri on proliferation and biofilm formation by Escherichia coli and Pseudomonas aeruginosa. Regulatory Mechanisms in Biosystems, 10(2), 251-256. https://doi.org/10.15421/021938

[24] Lindquist, J. A., \& Mertens, P. R. (2018). Cold shock proteins: from cellular mechanisms to pathophysiology and disease. Cell Communication and Signaling, 16(1), Article 63. https://doi.org/10.1186/ s12964-018-0274-6

[25] Abhisingha, M., Dumnil, J., \& Pitaksutheepong, C. (2017). Selection of Potential Probiotic Lactobacillus with Inhibitory Activity Against Salmonella and Fecal Coliform Bacteria. Probiotics and Antimicrobial Proteins, 10(2), 218-227. https://doi.org/10.1007/ s12602-017-9304-8

[26] Pancheniak, E. de F. R., Maziero, M. T., Rodriguez-León, J. A., Parada, J. L., Spier, M. R., \& Soccol, C. R. (2012). Molecular characterisation and biomass and metabolite production of Lactobacillus reuteri LPB P01-001: a potential probiotic. Brazilian Journal of Microbiology, 43(1), 135-147. https://doi.org/10.1590/s1517-83822012000100015

[27] Jamalifar, H., Rahimi, H., Samadi, N., Shahverdi, A., Sharifian, Z., Hosseini, F., Eslahi, H., \& Fazeli, M. (2011). Antimicrobial activity of different Lactobacillus species against multi- drug resistant clinical isolates of Pseudomonas aeruginosa. Iranian journal of microbiology, $3(1), 21-25$.

[28] Chen, C. -C., Lai, C. -C., Huang, H. -L., Huang, W. -Y., Toh, H. -S. Weng, T. -C., Chuang, Y. -C., Lu, Y. -C., \& Tang, H. -J. (2019). Antimicrobial Activity of Lactobacillus Species Against Carbapenem-Resistant Enterobacteriaceae. Frontiers in Microbiology, 10, Article 789. https:// doi.org/10.3389/fmicb.2019.00789

[29] Engels, C., Schwab, C., Zhang, J., Stevens, M. J. A., Bieri, C., Ebert, M. -O., McNeill, K., Sturla, S. J., \& Lacroix, C. (2016). Acrolein contributes strongly to antimicrobial and heterocyclic amine transformation activities of reuterin. Scientific Reports, 6(1), Article 36246. https:// doi.org/10.1038/srep36246

[30] Tajkarimi, M., \& Ibrahim, S. A. (2011). Antimicrobial activity of ascorbic acid alone or in combination with lactic acid on Escherichia coli $0157: \mathrm{H7}$ in laboratory medium and carrot juice. Food Control, 22(6), 801-804. https://doi.org/10.1016/i.foodcont.2010.11.030 